\title{
Ethical aspects in tissue research: thematic analysis of ethical statements to the research ethics committee
}

Arja Halkoaho ${ }^{1 *}$, Anna-Maija Pietilä2$^{2}$, Mari Vesalainen ${ }^{3}$ and Kirsi Vähäkangas ${ }^{3}$

\begin{abstract}
Background: Many studies have been published about ethics committees and the clarifications requested about the submitted applications. In Finland, ethics committees require a separate statement on ethical aspects of the research in applications to the ethics committee. However, little is known about how researchers consider the ethical aspects of their own studies.
\end{abstract}

Methods: The data were collected from all the applications received by the official regional ethics committee in the Hospital District of Northern Savo during 2004-2009 $(n=688)$. These included a total of 56 studies involving research on tissue other than blood. The statements by the researchers about the ethics about their own research in these applications were analyzed by thematic content analysis under the following themes: recruitment, informed consent, risks and benefits, confidentiality and societal meaning.

Results: The researchers tended to describe recruitment and informed consent process very briefly. Usually these descriptions simply stated who the recruiter was and that written consent would be required. There was little information provided on the recruitment situation and on how the study recruiters would be informed. Although most of the studies were clinical, the possibility was hardly ever discussed that patients could fail to distinguish between care and research.

Conclusion: The written guidelines, available on the webpages of the ethics committee, do not seem to be enough to help researchers achieve this goal. In addition to detailed guidelines for researchers, investigators need to be taught to appreciate the ethical aspects in their own studies.

Keywords: Thematic content analysis, Ethical views of scientists, Application to ethics committee, Informed consent, Recruitment

\section{Background}

Incidents of questionable practices in human biomedical research in the history have triggered the need for international regulations e.g. the Nuremberg Code in 1947 and later the Declaration of Helsinki in 1964. These define the ethical principles of medical research involving human subjects. In the past decades, a number of regulations about medical research have been issued at both the international and national levels [1]. According to

\footnotetext{
*Correspondence: arja.halkoaho@kuh.fi

${ }^{1}$ Faculty of Health Sciences, University of Eastern Finland, Research Unit/ Research Ethics Committee, University Hospital of Kuopio, P.O Box 1777 70210 Kuopio, Finland

Full list of author information is available at the end of the article
}

the Declaration of Helsinki, a pre-evaluation of the research plan should be performed by an independent research ethics committee [1,2]. According to the current Finnish legislation, five health care districts have official research ethics committees that evaluate all biomedical studies on humans and human tissues from an ethical and legal perspective [3].

Studies investigating the process of ethical review have revealed that most of the clarifications requested from the researchers by the committees are concerned with the informed consent process $[4,5]$. There may be other causes for clarification requests e.g. failure to comply with correct procedures, missing information and discrepancies [6]. In studies on the evaluation process itself,

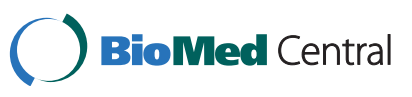


the critical aspects have included the evaluation time [7], a lack of uniformity in application forms and variations in the approval procedures adopted by different committees within the same country $[8,9]$.

Whitney and coworkers [10] focused on the opinions of researchers about the functions of the Independent Review Board (IRB) system. Their results indicated that some scientists consider the IRB system to be cumbersome by requiring completion of incomprehensible consent forms that focus too much on details and which seem to be intended to protect the institution rather than the research subjects [10]. In addition, failure of assessing risks and benefits, scientific validity and handling of consent procedures has been criticized by Paul [11]. Taylor and coworkers suggested that one possibility to speed up the evaluation process would be to invite the principle investigator to attend the review meetings [12]. Good communication between the scientists and the ethics committee is critical if one wishes to achieve a thorough consideration of all of the ethical aspects of research. Prior attention should be paid beforehand to ethical aspects if one wishes to guarantee the protection of research participants as well as making sure that there are no misunderstandings about the goals of the study [12-14]. Education and training are also considered important for IRB members [15].

Several ethical aspects, especially those involving tissue research, have been highlighted in the literature.
Legislation about the use of human tissue in scientific research is regarded as important $[16,17]$ and not unexpectedly, informed consent and autonomy in all human research are listed as central issues [17-20]. Today, the challenges of data protection and good research governance are emerging with the development of large tissue and gene banks [17]. Another example of a specific type of tissue research is human placental perfusion studies which have recently been under scrutiny from an ethical point of view [20-23].

The purpose of this study was to evaluate the ethical statements of principal investigators. Such statements are required by the official Research Ethics Committee of the Hospital district of Northern Savo. We limited this study to tissue research, excluding studies involving only blood samples.

\section{Methods}

\section{Data collection}

The data were collected from applications received by the Official Regional Ethics Committee of the Hospital District of Northern Savo during 2004-2009. In the years 2004-2005, the application form had a space for ethical considerations. However, it was possible to include a separate statement sheet as an attachment. At that time, there were no explicit guidelines concerning the structure of the ethics statement. From the beginning of 2006, a separate statement sheet on research ethics was required to be

Table 1 Required documents in tissue research by the official Research Ethics Committee of Hospital District of Northern Savo

\begin{tabular}{|c|c|c|c|}
\hline $\begin{array}{l}\text { Documents required } \\
\text { by the research } \\
\text { ethics committee }\end{array}$ & Required main contents & $\begin{array}{l}\text { Justification for the } \\
\text { need }\end{array}$ & Relevant legislation \\
\hline Application form & $\begin{array}{l}\text { General detailed } \\
\text { information of the study } \\
\text { (e.g. scientists, place of study) }\end{array}$ & $\begin{array}{l}2004-2005 \text { included } \\
\text { the ethics statement } \\
\text { by principal investigator }\end{array}$ & Not based on law, administrative order \\
\hline Study Plan & All scientific details of the study & Scientifically essential & Medical Research Act 488/1999 \\
\hline Information form & $\begin{array}{l}\text { All information about the } \\
\text { study for the potential } \\
\text { participants }\end{array}$ & $\begin{array}{l}\text { To check that it } \\
\text { is understandable by } \\
\text { lay people }\end{array}$ & $\begin{array}{l}\text { Medical Research Act 488/1999, } \\
\text { Act of Medical Use of Human } \\
\text { Organs and Tissues 101/2001 }\end{array}$ \\
\hline Consent form & $\begin{array}{l}\text { Clarification for what the } \\
\text { participants are actually } \\
\text { consenting }\end{array}$ & $\begin{array}{l}\text { Signed permission of } \\
\text { the participant to } \\
\text { be involved in the } \\
\text { study }\end{array}$ & Medical Research Act 488/1999 \\
\hline $\begin{array}{l}\text { Separate statement } \\
\text { about research ethics } \\
\text { by the principal } \\
\text { investigator }\end{array}$ & $\begin{array}{l}\text { Ethical justification of } \\
\text { the study; how ethical } \\
\text { principles will be taken } \\
\text { into on account in practice }\end{array}$ & $\begin{array}{l}\text { To ensure legally } \\
\text { and ethically defensible } \\
\text { practices }\end{array}$ & $\begin{array}{l}\text { Not based on law; practice of the } \\
\text { research ethics committee }\end{array}$ \\
\hline $\begin{array}{l}\text { Document explaining the } \\
\text { registry of personal } \\
\text { data files }\end{array}$ & $\begin{array}{l}\text { Included personal data, } \\
\text { access of data, storage } \\
\text { and disposal, } \\
\text { responsible person }\end{array}$ & To ensure personal data protection & Personal Data Act 523/1999 \\
\hline $\begin{array}{l}\text { Other documents } \\
\text { e.g. questionnaire, } \\
\text { letters, advertisements }\end{array}$ & $\begin{array}{l}\text { Type and contents } \\
\text { depend on the } \\
\text { particular study }\end{array}$ & $\begin{array}{l}\text { To check understandability, } \\
\text { legality and discretion }\end{array}$ & Medical Research Act 488/1999 \\
\hline
\end{tabular}


submitted as an attachment to the application form. This was intended to include the following topics: justification for the research (including societal meaning), informed concent process, voluntariness, and recruitment process, whether any vulnerable groups (e.g. children or pregnant women) would be included, confidentiality, and evaluation of risks and benefits.

The data were manually collected by two authors $\mathrm{AH}$, MV) from all the applications sent to the ethics committee during the defined years $(n=688)$. Although the material was collected by two researchers, the multidisciplinary research group discussed the selected studies. Studies planning to include only a blood sample, or tissue from a deceased person were excluded. Altogether 56 cases involving tissue research were available. Ethics committee guidelines listing the required documents are available in the Internet (www.kuh.fi; Table 1).

This research project received an administrative approval by the participating hospital. According to the Finnish law [3] this type of study does not need the approval from an official research ethics committee. The data was stored in a locked place and coded for analysis.

\section{Data analysis}

Within the documents, the data were analyzed both qualitatively and quantitatively according to five themes: recruitment, informed consent, risk and benefits, confidentiality and societal meaning of the research. The statements were read by $\mathrm{AH}$ and meaningful concepts and information were grouped under the selected themes and a thematic content analysis was performed $[24,25]$. If a theme was addressed even in one sentence, this was included as a statement within the theme. Although the material was analysed by one researcher, the multidisciplinary research group discussed the results at all stages of the analysis. The research group also worked together in reviewing the conceptualisation process and the selected concepts by confirming the validity of the study $[24,25]$. The content of the themes (Table 2) was formulated according to the literature [2] and previous studies of our research group $[20,22,23]$ as well as taking into consideration the instructions of the ethics committee.

\section{Results}

The selected cases represented different types of tissues, e.g. cancerous tissue, placental tissue, fatty tissue, brain and neurons, gynecological tissues and samples from the gastrointestinal tract. All of the application forms from the years 2004-2005 contained text about ethical aspects of the research project. In addition, a separate statement of research ethics was included in $8 / 24$ of these statements. In 2006-2009, after the new guidelines were implemented by the ethics committee, all of the researchers submitted a separate statement as required in the guidelines.

There were differences in the contents of the statements both when comparing the years 2004-2005 with 2006-2009, and between the statements within these groups. In general, the statements varied from a simple statement that the Declaration of Helsinki was taken into account, to detailed descriptions of many aspects of research ethics (Table 3).

\section{Recruitment and informed consent}

The recruitment situation was described in more than a half $(31 / 56)$ of all the studied statements (Table 3). On the other hand, recruitment was addressed only in four of the statements from the years 2004-2005 and generally only the study population was defined (e.g. diabetics). In the statements from the years 2006-2009, the recruitment process was explained in $27 / 32$ of the statements and more information was given; e.g. about the planned recruiters, recruitment situation and how the recruiters would be informed. In 5/56 statements, the researchers had actually considered that the recruitment situation was sensitive and this fact was described in detail. These five statements also included a plan to include information about the life-situation of the research participants during the recruitment. The rest of the statements mentioned very briefly the plan for recruitment and the informed consent process: who would be doing the recruitment and how the information was planned to be given to the participants. In most cases (46/56), the recruitment was planned to take place during clinical treatment e.g. surgery or birth. The planned recruiters varied (nurses, physicians or researchers).

The informed consent process was described in 33 of the 56 statements. In general, the most common description of the informed consent process stated that there would be a request for written informed consent and the possibility to refuse participation. Voluntariness and the possibility to discontinue the research were described in 6/56 statements. A total of $8 / 56$ statements mentioned that time would be given for the invited participants to consider their decision. However, in most cases, the actual time allocated for a decision was not defined.

\section{Handling and confidentiality of personal information}

Handling and confidentiality of personal information were described in 36/56 of the statements. Coding was correctly explained in 29/56 and anonymization in 5/56. In these cases, coding and anonymization were defined in a way that allowed the reader to understand what the author meant by these terms. However, in 3/56 statements, the meaning of anonymity (no possibility to link 
Table 2 Preconceived aspects from the literature within the themes $[2,20,22,23]$

\begin{tabular}{ll}
\hline The main aspects & Contents sought out \\
\hline - Recruitment & - Situation at the time of the research \\
- The process of decision about participation & - How the information was planned to be given to recruiters \\
- Possible vulnerable groups & - How the information was planned to be given to invited participants \\
- Informed consent and voluntariness & - Comprehension of written and oral information \\
& - Voluntariness \\
- Appreciation of voluntariness \\
- Risks and benefits of the research for participants & - Meaning, significance and stressfulness of the research for the participants \\
- Views about societal meaning & - Purely research or within clinical care \\
& - Confidentiality, concerns for preserving privacy \\
\hline
\end{tabular}

data to a person) and coding was confused (as an example "samples will be anonymized and coded"). In 28/ 56 cases, there was information provided about which individual would have the code key and in 18/56 it was explained how the data would be stored.

Risks and benefits, and societal meaning of the research Considerations about risks and benefits were written in $80.4 \%$ of all the statements. In most of these cases, it was stated that the tissue would be removed during a clinical procedure. The authors often stated that therefore no risk for research participants would be envisioned, and/or mentioned that the tissue was regarded as waste. Additional samples (a separate tissue sample, other samples, e.g. blood) were, however, explained in detail and considered as an extra risk. On the other hand, in all cases, the difference between research and care was left unexplained. Individual research participants in 11/56 cases were informed that they would not gain any direct benefit from tissue donation. However, the, scientists did state that benefits would be conferred through certain other factors, for instance by obtaining results of blood tests or through health education. In some studies, this type of information was planned to be given to the potential participants in an information leaflet.

In their consideration of ethical aspects, four researchers mentioned the possibility of unexpected results and how the research participants in such a case would be given the best possible care. None of the statements contained any consideration under the term "societal meaning". However, the following aspects mentioned by the scientists could be regarded as belonging to this category: 11/56 mentioned that one benefit would be the development of new methods, and 13/56 referred to benefits for public health care in general (e.g. clarification of disease mechanisms providing possibilites for preventive actions and better care).

\section{Discussion}

Although there have been publications on the ethical aspects of tissue research, as far as we are aware, none have so far handled the ethical statements of researchers. The Research Ethics committee of Hospital District of Northern Savo expects that a separate statement sheet

Table 3 Presence of ethical themes in the analyzed statements

\begin{tabular}{lccc}
\hline Theme & $\begin{array}{c}\text { Years 2004-2005 }(\mathbf{n = 2 4 )} \\
\text { No. (\% of total) }\end{array}$ & $\begin{array}{c}\text { Years 2006-2009 }(\mathbf{n}=\mathbf{3 2}) \\
\text { No. (\% of total) }\end{array}$ & $\begin{array}{c}\text { Total }(\mathbf{n}=\mathbf{5 6}) \\
\text { No. (\% of total) }\end{array}$ \\
\hline Recruitment & $4(16.7)$ & $27(84.4)$ & $31(55.4)$ \\
Informed consent & $9(37.5)$ & $24(75.0)$ & $33(58.9)$ \\
Risks and benefits & $16(66.7)$ & $29(90.6)$ & $45(80.4)$ \\
Confidentiality & $10(41.7)$ & $26(81.3)$ & $36(64.3)$ \\
Societal meaning & $6(25.0)$ & $13(40.6)$ & $19(33.9)$ \\
\hline
\end{tabular}


should be submitted to the research ethics committee. One interesting and important point emerging from our results was the insufficient handling of the key ethical aspects in many of the applications for the research ethics committee. On the other hand, only the official forms and separate statements about ethical aspects were studied and it is possible that the research plan in some cases included some of this information. It was evident that, in general, the statements were less structured in 2004-2005 than in 2006-2009, when the ethics committee had already formulated the requirements for the ethical statements and their content. Thus, in our case, the formal requirement and advice by the ethics committee had a positive effect on the quality of the written statements. In the study by Antes and coworkers [26] it was disturbing that in some cases the reasoning strategies, such as awareness of the situation and consideration of personal motivations, improved but at the same time there was a decline in seeking help and considering others' perspectives. Mentoring in research ethics is a two-way road also with the possibility to both increase and decrease ethically good conduct [27]. One postulated way to improve ethics in biomedical research is to conduct an ethics consultation with a bioethicist [28]. However, at present it is still unclear when, how and by whom research ethics instruction would be most beneficial. In addition, there needs to be a systematic study of how such measures could affect the actual ethical conduct of researchers in addition to recognition and formulation of ethical aspects and their handling in written statements.

According to the general consensus, ethical considerations should include details of the recruitment and informed consent process with the following elements: competence, voluntariness, understanding and consent $[1,2]$. Still, only a few of the studied statements discussed how competence and understanding would be ensured. Voluntariness was usually mentioned very briefly in one sentence. In our earlier studies $[20,22,23]$ in accordance with the literature [29], we have found the importance of considering the actual situation when the signature is being gained from the participant. In this study, the ethical aspects about obtaining the signature for the consent form were almost forgotten by the researchers, at least according to their statements. Very few statements mentioned how much time would be available for the participant to make a decision. However, the time given has been considered an important detail by many authors [e.g. 13,30,31].

A major issue is how to educate the recruiters when they are not part of the research group: how to inform nurses/doctors about the research project in such a way that they can provide relevant information to the participants [22,23]. This aspect was missing in most of the statements, when the recruiter came from outside the research group. Furthermore, there was a failure to explain the difference between patient care and research to the patient. This so-called therapeutic misconception, which means that the participant thinks that the study is part of some clinical treatment, is a common situation in practice $[32,33]$. To obtain a genuine informed consent, these aspects should be discussed when planning the research. Furthermore, in our previous studies $[20,22,23]$ and other authors $[34,35]$ have observed that even if planning is done carefully and information is given to the recruiters, the recruitment in practice can be very challenging.

The guidelines of the Ethics Committee of the Hospital District of Northern Savo instruct researchers to consider the justification for the research in their ethical statements (Table 1). Furthermore, the Declaration of Helsinki, as well as other regulations, requires that research should be based on earlier literature and this should be demonstrated in the research plan [1]. One of the most important justifications for biomedical research is its usefulness for patients and patient care in the form of applicable knowledge for diagnostic, therapeutic and prognostic purposes. Nonetheless, the studied statements provided little information on the societal meaning of the study. Similarly to confidentiality, societal justification is a topic that may not be perceived as an ethical aspect, and most likely it has been described in the research plan.

It is unfortunate that the terminology in the literature is confusing, for instance, the definitions of anonymity and coding leave room for misunderstanding [13]. It is clearly challenging to make the studies understandable to lay people and such poorly defined details confuse both researchers and the participants. Thus, the scientific community should attempt to clarify the scientific terminology, which actually may be regarded also as an ethical requirement in human studies.

In future tissue research, it would be important to study whether it makes a difference to the participants if the tissue is removed simply for research purposes or if it is leftover tissue from routine operations. In addition, it would also be interesting to determine how people perceive the difference between the situation of healthy volunteers asked to donate to tissue banks compared to the views of actual patients asked to donate left-over tissue. Considering that this study was carried out in one center only, we do not know the generalizability of our results and comparison of investigations from different centers would be helpful in further studies.

\section{Conclusion}

In conclusion, the justification of the research from an ethical point of view was missing from the majority of 
the statements. It is noteworthy that even after the requirement by the Ethics Committee for an ethical consideration became mandatory, a significant percentage of applications lacked considerations of recruitment, informed consent and confidentiality. In view of the rapid developments occurring in biomedicine, it is clear that there is a need for continuing education in research ethics. In addition, a dialogue between the scientists and society would provide a better foundation for scientists to take the societal aspects of their research into account.

\section{Competing interests}

The authors declared that they have no competing interest.

\section{Authors' contributions}

$\mathrm{KV}, \mathrm{AMP}$ and $\mathrm{AH}$ designed the study. $\mathrm{AH}$ and $\mathrm{MV}$ collected the data. $\mathrm{AH}$ analyzed the data and discussed the analysis with KV and AMP. KV, AMP and $\mathrm{AH}$ wrote the paper. All authors read, commented and accepted the final version.

\section{Funding}

This study has financially supported by Kuopio University Hospital EVOfunding.

\section{Acknowledgement}

We would like to dedicate this article to the late Prof. Tuula Pirttilä, former Chair of the Ethics Committee of Hospital District of Northern Savo. Tuula had the rare skill through discussions and education to encourage scientists to consider ethical aspects of their research, and originally introduced the idea for this study. The research program was initiated within the EU-project NewGeneris (Contract no. FOOD-CT-2005-016320).

\section{Author details}

${ }^{1}$ Faculty of Health Sciences, University of Eastern Finland, Research Unit/ Research Ethics Committee, University Hospital of Kuopio, P.O Box 1777 70210 Kuopio, Finland. ${ }^{2}$ Faculty of Health Sciences, University of Eastern Finland, Social and Health Care Services, Kuopio, Finland. ${ }^{3}$ Faculty of Health Sciences, University of Eastern Finland, Kuopio, Finland.

Received: 13 September 2011 Accepted: 30 July 2012

Published: 8 August 2012

\section{References}

1. WMA: 2011 World medical association. Declaration of Helsinki. 2011. http:// www.wma.net/en/30publications/10policies/b3/index.html. read 6.4

2. Beauchamp TL, Childress JF: Principles of Biomedical Ethics. Oxford University Press: Fifth edition; 2001.

3. Medical Research Act 488/1999, 294/2004, 794/2010). 2011. http://www.finlex fi/fi/laki/alkup/2010/20100794 read 6.4

4. Bueno M, Brevidelli MM, Cocarelli T, Santos G, Ferraz MA, Mion D: Reason for resubmission of research projects to the research ethics committee of university hospital in São Paulo Brazil. Clinics 2009, 64:831-836.

5. Keinonen T, Nieminen S, Saano V, Ylitalo P: Acceptability and Profile of the Clinical Drug Trials Underway in Finnish University Hospitals in the 1990s: Applications Reviewed by Ethics Committees. Methods Find Exp Clin Pharmacol 2001, 23:415-423.

6. Angell E, Dixon-Woods M: Do research ethics committees identify process errors in applications for ethical approval? J Med Ethics 2009, 35:130-132.

7. Porcu L, Poli D, Torri V, Di Tullio MC, Cinquini M, Bajetta E, Labianca R, DiCostanzo F, Nitti D, Floriani I: Impact of recent legislative bills regarding clinical research on Italian ethics committee activity. J Med Ethics 2008, 34:47-750.

8. Seiler CM, Kellmayer P, Kienle P, Büchler MW: Knabel HB \& INSECT Study Group: assessment of the ethical review process for nonpharmacological multicentre studies in Germany on the basis of a randomized surgical trial. J Med Ethics 2007, 33:113-118.
9. Driscoll A, Currey J, Worral-Carter L, Steward S: Ethical dilemmas of a large national multi-center study in Australia: time for some consistency. I Clin Nurs 2006, 17:2212-2220.

10. Whitney SN, Alcer K, Schneider CE, McCullough LB, McGuire AL, Volk RJ: Principal Investigator Views of the IRB system. Int J Med Sci 2008, 5:68-72.

11. Paul C: Health researcher' views of ethics committee functioning in New Zealand. N Z Med J 2000, 113:210-214.

12. Taylor HA, Currie P, Kass NE: A study to evaluate the effect of investigator attendance on the efficiency of IRB review. IRB 2008, 30:1-5.

13. Vähäkangas K: Ethical aspects of molecular epidemiology of cancer. Carcinogenesis 2004, 25:465-471.

14. Merlo DF, Knudsen LE, Matusiewicz KM, Niebroj L, Vähäkangas K: Ethics in studies on children and environmental health. J Med Ethics 2009, 33:408-413.

15. Athula Sumathipala A, Siribaddana S, Hewage S, Lekamwattage M Athukorale M, Siriwardhana C, Murray J, Prince M: Informed consent in Sri Lanka: a survey among ethics committee members. BMC Med Ethics 2008, 9:10. doi:10.1186/1472-6939-9-10.

16. Campbell AV, McLean SAM, Gutridge K: Human tissue legislation:listening to the professionals. J Med Ethics 2008, 34:104-108.

17. Van Veen EB: Obstacles to European research projects with data and tissue: solution and further challenges. Eur J Cancer 2008, 44:1438-1450.

18. Siegel A, Anderson MW, Schmidt TC, Younger SJ: Informed consent to tissue donation: policies and practice. Cell Tissue Bank 2009, 10:235-240.

19. Steinmann M: Under the pretence of autonomy: contradictions in the guidelines for human tissue donation. Med Health Care Philos 2009, 12:281-289

20. Halkoaho A, Pietilä AM, Dumez B, VanDamme K, Heinonen S, Vähäkangas K: Ethical aspects of human placental perfusion: interview of the mothers donating placenta. Placenta 2010, 31:686-690.

21. Lind $U$, Knudsen $L E$, Mose $T$ : Participation in environmental health research by placenta donation - a perception study. Environ Health 2007, 6:36.

22. Halkoaho A, Vähäkangas K, Häggman-Laitila A, Pietilä AM: Views of midwives about ethical aspects: participation in placental perfusion studies. Midwifery 2012, 28:131-137.

23. Halkoaho A, Pietilä AM, Vähäkangas K: Ethical aspects in placental perfusion studies: views of the researchers. Placenta 2011, 32:511-515.

24. Hsieh H-F, Shannon SE: Three approaches to qualitative content analysis. Qual Health Res 2005, 15:1277.

25. Tong A, Sainsbury P, Craig J: Consolidated criteria for reporting qualitative research (COREQ): a 32-item checklist for interviews and focus groups. Int I Qualt Health Care 2007, 19:349-357.

26. Antes L, Wang X, Mumford M, Brown R, Connelly S, Devenport L: Evaluating the effects that existing instructions on responsible conduct of research has on ethical decision making. Acad Med 2010, 85:519-526.

27. Anderson M, Horn A, Risbey K, Ronning E, De Vries R, Martinson B: What do mentoring and training in the responsible conduct of research have to do with scientists' misbehavior? Findings from a National Survey of $\mathrm{NIH}-$ Funded Scientists. Acad Med 2007, 82:853-860.

28. McCormick J, Boyce A, Cho M: Biomedical scientists' perceptions of ethical and social implications: is there a role for research ethics consultations? PLoS One 2009, 4(3):e4659. doi:10.1371/journal. pone.0004659

29. Behrendt C, Gölz T, Roesler C, Bertz H, Wunsch A: What do our patients understand about their trial participation? Assessing patients understanding of their informed consent consultation about randomised clinical trials. J Med Ethics 2011, 37-74:74-80.

30. Länsimies-Antikainen $\mathrm{H}$, Pietilä AM, Kiviniemi V, Rauramaa R, Laitinen T: Evaluation of participant comprehension of information received in an exercise and diet intervention trial: the DR's EXTRA study. Gerontology 2010, 56:291-297.

31. Lynöe N, Näsström B, Sandlund M: Study of the quality of information given to the patients participating in a clinical trial regarding chronic hemodialysis. Scand J Urol Nephrol 2004, 38:517-520.

32. Lidz CW, Appelbaum PS, Grisso T, Renaud M: Therapeutic misconception and the appreciation of risks in clinical trials. Soc Sci Med 2004, 58:1689-1697.

33. Appelbaum PS, Lidz CW: Re-evaluating the therapeutic misconception: response to Miller and Joffe. Kennedy Inst Ethics J 2006, 16:367-373 
34. Lavori PW, Wilt TJ, Sugarman J: Quality assurance questionnaire for professionals fails to improve the quality of informed consent. Clin Trials 2007, 4:638-649.

35. Jerosch-Herold C, Shepstone L, Vaughan S, Barrett B, Larson D, Chojnowski A: A questionnaire-based survey of participants' decisions regarding recruitment and retention in a randomized controlled trial - lessons learnt from the SCoRD trial. Contemp Clin Trials 2011, 32:363-368.

doi:10.1186/1472-6939-13-20

Cite this article as: Halkoaho et al.: Ethical aspects in tissue research:

thematic analysis of ethical statements to the research ethics committee. BMC Medical Ethics 2012 13:20.

\section{Submit your next manuscript to BioMed Central and take full advantage of:}

- Convenient online submission

- Thorough peer review

- No space constraints or color figure charges

- Immediate publication on acceptance

- Inclusion in PubMed, CAS, Scopus and Google Scholar

- Research which is freely available for redistribution 